\title{
The Effect of Risk Factors on Quality of Life in Childhood Asthma
}

\section{Çocukluk Çağı Astımında Risk Faktörlerinin Yaşam Kalitesine Olan Etkisi}

\section{Emin OZKAYA, Ozgur SANCAR, Mehmet Rusen DUNDAROZ}

Department of Pediatric Allergy and Immunology, Bezmialem Vakif University Faculty of Medicine, Istanbul, Turkey

\section{ABSTRACT}

Objective: This study was conducted to assess the Quality of Turkish children with asthma and its associated risk factors by using the PAQLQ (Pediatric Asthma Quality Of Life Questionnaire).

Methods: One hundred fifty children with asthma aged between 7-17 who were attending the out-patient clinic of the Pediatric Allergy and Immunology section were selected for the study between March 2009-March 2011. Asthma severity was made according to the Global Initiative for Asthma-GINA. Quality of Life (QoL) was measured by the Turkish version of the Pediatric Asthma Quality Of Life Questionnaire (PAQLQ). A total QoL score was calculated by the mean of all items. Patients' PAQLQ sores of different levels of disease were analyzed by ANOVA.

Results: One hundred fifty (93 boys) children were included in our study. The mean time since asthma diagnosis was 6.5 years $( \pm 2.8)$. There were statistically significant PAQLQ score differences among children with mild, moderate, and severe asthma $(\mathrm{p}<0.001)$. There was a negative inverse relation between passive exposure of smoking and the number of family member and PAQLQ sores. PAQLQ sores of children who also had allergic rhinitis symptoms were significantly lower than those who had no allergic rhinitis symptoms

Conclusion: This study showed that children with asthma have significantly low QoL scores. Passive cigarette exposure and additional allergic rhinitis affect PAQLQ scores negatively.

Key Words: Asthma, children, quality of life, risk factors, questionnaire

\section{ÖZET}

Amaç: Bu çalışmada, astımlı çocuklarda, 'Çocuklar İçin Astım Yaşam Kalitesi Ölçeği (ÇAYKÖ, PAQLQ: Pediatric Asthma Quality Of Life Questionnaire)' kullanılarak, yaşam kalitesinin değerlendirilmesi ve bunu etkileyen risk faktörlerini belirlemeyi amaçladık.

Yöntemler: Çalışma, Mart 2009-2011 tarihleri arasında Çocuk Astım-Alerji Polikliniğine başvuran 7-17 yaş arası astım tanılı 150 hasta ile yapılmıştır. Astım şiddetinin belirlenmesi uluslararası astım tedavi rehberine (Global Initiative for Asthma-GINA) göre yapıldı. Çalışmaya katılmayı kabul eden hastalardan 'Çocuklar İçin Astım Yaşam Kalitesi Ölçeği’nin (ÇAYKÖ) Türkçe versiyonunu okuyarak doldurmaları istendi. Yüksek skor yaşam kalitesinin iyi olduğunu göstermekteydi. Hastalık şiddetine göre gruplandırılan hastaların ÇAYKÖ skorları 'Tek yönlü varyans analizi (ANOVA)' ile karşılaştırılmıştır.

Bulgular: Çalışmaya 93'ü erkek olmak üzere toplam 150 hasta katılmış olup, hastaların yaş ortalaması 9,3 yıl olarak hesaplanmıştır. Hastalara astım tanısı konulma yaşı ortalama 6,5 yıldır. Çalışmaya katılan hastaların ÇAYKÖ'de yer alan toplam skor ortalamasının astımın şiddetine göre istatistiksel olarak anlamlı farklılık gösterdiği saptanmıştır $(\mathrm{p}<0,001)$. Pasif sigara maruziyeti ve evdeki birey sayısı ile yaşam kalite skorları arasında ters yönde ama zayıf bir korelasyon bulunmuştur. Alerjik rinit öyküsü bulunan hastaların ÇAYKÖ skorlarının, alerjik rinit öyküsü olmayan hastalara göre daha düşük olduğu gözlenmiştir.

Sonuç: Astımlı çocukların yaşam kalitesi skorlarının anlamlı derecede düşük olduğunu göstermiştir. Hastalarımızın pasif sigara maruziyeti ve alerjik rinit öyküsü oranlarının yüksek olduğu ve bu faktörlerin yaşam kalitesini olumsuz etkilediği saptanmıştır.

Anahtar Sözcükler: Astım, çocuk, hayat kaltesi, risk faktörleri, anket 


\section{Giriş}

Astım çocukluk çağında en sık görülen ve prevalansı dünya çapında gittikçe artan kronik bir hastalıktır $(1,2)$. Çocukluk çağı astımı hastaneye defalarca yatış, okul devamsızlığı ve diğer günlük aktivitelerde azalma gibi sonuçlara neden olmaktadır. Astımı olan çocukların fiziksel, sosyal ve emosyonel durumları bozulmaktadır. Astım, çocukların hatta ebeveynlerin bile yaşam kalitesini etkileyebilmektedir $(3,4)$. Dünya Sağlık Örgütü (DSÖ) yaşam kalitesini, kişinin yaşadığı kültür ve değer sistemleri çerçevesinde, amaçları, beklentileri, standartları ve ilgileri ile ilişkili olarak yaşamdaki pozisyonunu algılaması şeklinde tanımlar. Kişinin fiziksel sağlığı, psikolojik durumu, inançları, sosyal ilişkileri ve çevresiyle ilişkisinden karmaşık bir yolla etkilenen geniş bir kavramdır. Bu tanım, yaşam kalitesinin kültürel, sosyal ve çevresel kavramlara iyice gömülmüş subjektif bir değerlendirme olduğu görüşünü yansıtmaktadır (5).

Yaşam kalitesinin değerlendirilmesi doktora, uyguladığı tedaviyi sadece fiziksel olarak değil aynı zamanda yaşam kalitesi sonuçları açısından da daha iyi anlayabilme imkanı sunmaktadır (6). Pediatrik astımda yaşam kalitesinin hem çocuklar hem de ebeveynler açısından değerlendirilmesi günümüzde pratisyenler ve araştırmacılar arasında gittikçe artan bir ilgiyle karşılanmaktadır. Çünkü benzer değerlendirmeler hem tedavinin daha iyi anlaşlıp izlenmesine, hem de klinisyen ile hasta arasındaki iletişimin artmasına yardımcı olmaktadır (7). Yaşam kalitesi çocukluk çağı astımının tedavi sonuçlarının değerlendirilmesi için önemli bir göstergedir (8).

Astımın klinik olarak en önemli semptomları olan nefes darlığı, öksürük, hışıltılı solunum (wheezing), sigara dumanı ya da benzeri çevresel irritanlardan etkilenme, hava durumu değişikliklerinin kötü etkileri, viral enfeksiyonlarda geçirilen ataklar, uyku bozukluğu ve tedavi uygulamalarının oluşturduğu yan etkiler, zaman kısıtlaması vs. hastanın yaşam kalitesini etkileyen nedenlerdir. Bunların varlığ hastanın psişik, sosyal ve emosyonel yaşamını bozacaktır (9). Bu sorunlar günlük yaşam içinde spor yapma, arkadaşlarıyla veya hayvanlarla oynama gibi hoşlandıkları aktivitelerden uzak kalmalarına ve sosyal yaşamları içinde kendilerini kötü hissetmelerine neden olur. Büyük çocuklar astım nedeniyle okuldan geri kaldığı için üzülür. Bu çocuklar duygusal problemlerin üstesinden gelmek zorundadır. Astım atağından korkmak, yapmak istedikleri şeyleri yapamamanın hayal kırıklığı, farklı hissetmek, dışlanmak, yaşıtlarına ayak uyduramamak gibi durumlar onları mutsuz eder (10).

Bu bilgiler ışı̆̆ında biz de Türkiye'de henüz çok fazla yapılmamış olan bu konuyla ilgili bir çalışma yaparak, astımlı çocuklarda, 'Çocuklar İçin Astım Yaşam Kalitesi Ölçeği (ÇAYKÖ, PAQLQ: Pediatric Asthma Quality Of Life Questionnaire)' kullanılarak, yaşam kalitesinin değerlendirilmesi ve bunu etkileyen risk faktörlerini belirlemeyi amaçladık.

\section{Yöntemler}

\section{Hasta Popülasyonu}

Çalışma, Mart 2009-2011 tarihleri arasında Çocuk Astım-Alerji Polikliniğine başvuran 7-17 yaş arası astım tanılı 150 hasta ile yapılmıştır. Çalışmamız 25.02.2009 tarih ve B.02.1.VGM.2.03.01 sayı ile hastane etik kurulundan onaylanmıştır.

Çocukların ailelerine çalışma hakkında bilgi verilerek bilgilendirilmiş onam formu imzalatıldıktan sonra, hastalar çalışmaya dahil edilmişlerdir. Çocukların ailelerinden alınan bilgiler ve hasta dosyasından elde edilen bulgular Hasta Profil Kaydı formuna işlenmiştir.

\section{Hastaların Sınıflandırılması}

Astım şiddetinin belirlenmesi genellikle uluslararası astım tedavi rehberine (Global Initiative for Asthma-GINA) göre yapılmaktadır (11). Bunun için semptomlar, ataklar, kısa etkili ß-2 agonist kullanım sıklığı ve solunum fonksiyonları dikkate alınmaktadır. Bu verilerin birlikte değerlendirilmesiyle astımlı hastalar, intermittan, hafif persistan, orta persistan ve ağır persistan olmak üzere 4 gruba ayrılmıştır.

\section{Çocuklar için Astım Yaşam Kalitesi Ölçeği (Çocuklar için Astım Yaşam Kalitesi Ölçeği (ÇAYKÖ)}

Çalışmaya katılmayı kabul eden hastalardan 'Çocuklar için Astım Yaşam Kalitesi Ölçeği' nin (ÇAYKÖ) Türkçe versiyonunu okuyarak doldurmaları istenmiştir. Bu ölçek 7-17 yaş arası çocuklar için Juniper ve ark. (12) tarafından geliştirilmiş olup Türkçeye "Çocuklar İçin Astım Yaşam Kalitesi Ölçeği” adıyla Hasan Yüksel ve arkadaşları tarafından valide edilmiştir. ÇAYKÖ 'belirtiler', 'faaliyet kısıtlanması' ve 'duygusal işlev' olmak üzere 3 alt birim ve 23 sorudan oluşmaktadır . 10 sorudan oluşan 'belirtiler' alt biriminde $(4,6,8,10,12,14,16,18$, 20 ve 23) nefes darlığı, göğüste hırıltı, öksürük, göğüste sıkışma, yorgunluk sorgulanmaktadır. 8 sorudan oluşan 'duygusal işlev' alt biriminde $(5,7,9,11,13,15,17$ ve 21$)$ üzüntü, kırgınlık, korku, endişe, kızgınlık, kendini farklı ya da dışlanmış hissetme gibi duygular sorgulanmaktadır. 5 sorudan oluşan 'faaliyet kısitlanması' alt biriminde (1, 2, 3, 19 ve 22) fiziksel, sosyal, okul ve uyku durumları sorgulanmaktadır. Çalışmanın başında hastanın son 1 hafta boyunca 39 aktiviteden yapmakta en çok zorlandığı 3 tanesini seçmesi istenmiştir.

Ölçekteki her soru eşit ağırlıktadır. Kaydedilen puanlar doğrudan analiz edilip, sonuçlar hem toplam yaşam kalitesi, hem de her alan için "soru başına puan ortalaması" olarak hesaplanmıştır. Puanlama her madde için 1-7 arasında değişmektedir. 1; "her zaman" veya "aşırı derecede rahatsız oldum", 7; "hiçbir zaman" veya "hiç rahatsız olmadım” cevaplarına karşılık gelmektedir. Toplam yaşam kalitesi puanı bütün soruların puan ortalamasından hesaplanmışstır. Yüksek skor yaşam kalitesinin iyi olduğunu gösterir (12). 


\section{Solunum fonksiyon testleri (SFT)}

Solunum fonksiyon testi polikliniğimizde spirometre (Spirolab III, MIR Medical Int.Res., Roma, İtalya) cihazı ile yapilmıştır. Bu cihaz her gün kullanılmadan önce kalibre edilmektedir. Test öncesi hastalardan kısa etkili ß2 agonist ilaçlarını en az 6 saat, uzun etkili ß2 agonistleri en az 48 saat önce kesmeleri istenmiştir. Test sırasında FEV1 (Forced Expiratory VolumeBirinci saniyedeki zorlu ekspiratuvar akım), Peak expiratory flow (PEF), Zirve ekspiratuvar akım hızı), FEF25-75 (Forced Expiratory Flow 25-75\%- Zorlu vital kapasitenin \%25-75’i arasındaki ortalama akım) parametreleri en az üç kez tekrarlanarak en iyi sonuçlar değerlendirmeye alınmıştır. Olgulara $400 \mathrm{mcg}$ salbutamol inhalasyonu (ventolin inhaler ile 2 çekiş) yaptırılmış, 20 dakika sonra SFT tekrarlanmıștır. Solunum fonksiyon testlerinde FEV1'de \%12'lik artış geriye dönebilir obstrüksüyon (reverzibilite) olarak değerlendirilmiştir.

\section{İstatistiksel analiz}

İstatistiksel analizler için SPSS "Statistical Package for Social Sciences (SPSS) 16.0” programı kullanılmıştır. Hastalık şiddetine göre gruplandırılan hastaların ÇAYKÖ skorları 'Tek Yönlü Varyans Analizi (ANOVA)' ile karşılaştırılmışır. Hastaların demografik özellikleri, pasif sigara maruziyeti, klinik özellikleri, solunum fonksiyon testi değerleri ve kullandıkları astım ilaçlarıyla ÇAYKÖ skorları arasındaki ilişki 'Pearson Korelasyon' ve 'Ki-Kare' analizi ile test edilmiştir. Alerjik rinit ve ailesel atopi varlığına göre gruplandırılan hastaların ÇAYKÖ skorları 'Bağımsız Örneklerde t Testi' ile karşılaştırılmıştır. $p$ değerinin 0,05 den küçük olması istatistiksel olarak anlamlı kabul edilmiştir.

\section{Bulgular}

Çalışmaya 93'ü erkek olmak üzere toplam 150 hasta katılmış olup, hastaların yaş ortalaması 9,3 yıl olarak hesaplanmıştır. Hastalara astım tanısı konulma yaşı ortalama 6.5 yıldır. Hastaların demografik özellikleri Tablo 1'de gösterilmiştir. Çalışmaya katılan hastaların \%45'i GINA kılavuzuna göre hafif intermitan astım sınıfında iken, sadece 1 hastanın ağır persistan sınıfında olduğu saptandı. Hastaların son 1 yılda yaşadıkları atak sayısı $1,74 \pm 2,02$, son 6 aydaki okul devamsızlığı $3,55 \pm 5,08$ gün ve son 3 aydaki kısa etkili beta- 2 agonist kulla-

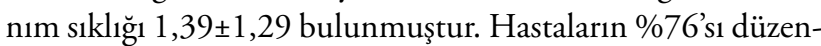
li olarak, çalışmanın yürütüldüğü çocuk alerji polikliniğinden takipli idiler. Hastaların astım nedeniyle yapmakta zorlandığı, ÇAYKÖ anketinde yer alan ve en fazla 3 tanesini işaretleyebildikleri faaliyetlerden ilk 10'u Tablo 2'de verilmiștir.

Çalışmaya katılan hastaların ÇAYKÖ'de yer alan toplam skor ortalamasının astımın şiddetine göre istatistiksel olarak anlamlı farklılık gösterdiği saptanmıştır (Şekil 1). Hastalığın şiddeti arttıkça hastaların ÇAYKÖ skorları belirgin olarak azalmaktaydı.

Hastaların demografik özellikleriyle ÇAYKÖ skorları arasında çok zayıf bir korelasyon saptanmış olup, bu ilişki istatis-

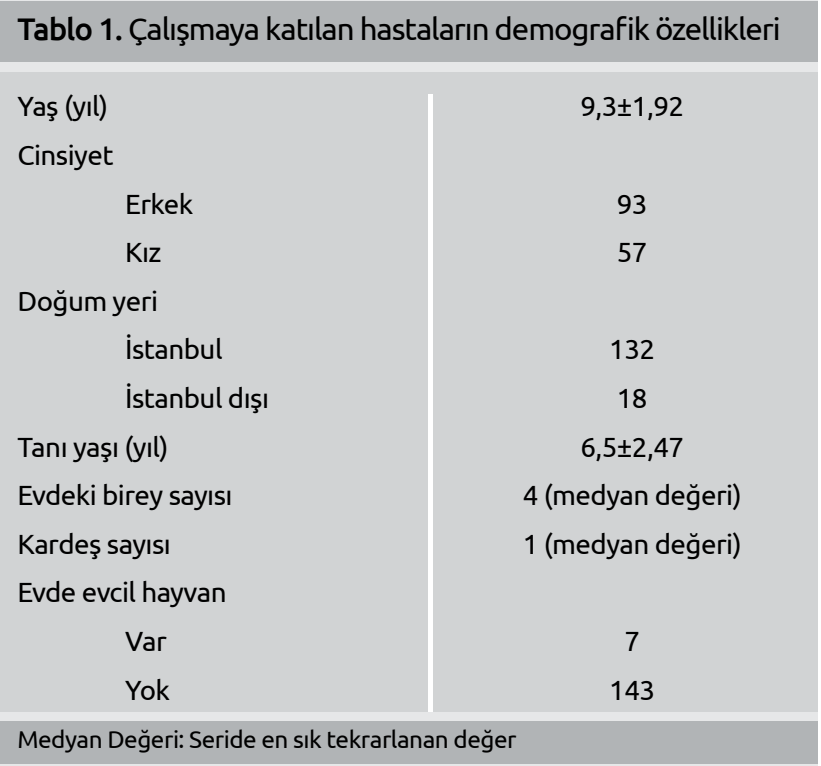

Tablo 2. Hastaların astım nedeniyle yapmakta zorlandığı faaliyetler
Faaliyet

\section{Koşma}

Futbol

Merdiven çıkma

Tenefüste oynama

Arkadaşlarla oynama

Bilgisayar kullanma

Yürüyüş

Uyuma

Basketbol

İp atlama
Hasta Sayısı

66

36

27

25

15

15

11

10

10

10 gibi pasif sigara maruziyeti ve evdeki birey sayısı ile yaşam kalite skorları arasında ters yönde ama zayıf bir korelasyon bulunmuştur. Ailesel atopi öyküsü bulunan hastaların ÇAYKÖ skorlarının, ailesinde atopi öyküsü olmayan hastalara göre daha düşük olduğu görülmüştür, ancak bu fark semptom skoru $(\mathrm{p}=0,036)$ dışındaki skorlar açısından istatistiksel olarak anlamlı bulunmamıştır. Alerjik rinit öyküsü bulunan hastaların ÇAYKÖ skorlarının, alerjik rinit öyküsü olmayan hastalara göre daha düşük olduğu gözlenmiştir ancak bu fark, semptom skoru $(\mathrm{p}=0,043)$ dışındaki skorlar açısından istatistiksel olarak anlamlı bulunmamıştır.

Hastaların klinik özellikleriyle ÇAYKÖ skorları arasındaki ilişki Tablo 4'de gösterilmiştir. Korelasyon analizine göre hastaların astım tanısı konduktan sonra geçen yıl sayısı arttıkça semptom skorlarının azaldığı, atak sıklığı ve kısa etkili beta- 2 agonist kullanımı arttıkça tüm ÇAYKÖ skorlarının azaldığı ve okul devamsızlı̆̆ı ile tüm ÇAYKÖ skorları arasında yine negatif yönde bir korelasyon olduğu istatistiksel olarak görülmektedir. Prick testi pozitifliği ile ÇAYKÖ skorları arasında 


\begin{tabular}{|c|c|c|c|c|c|c|c|c|}
\hline \multirow[t]{2}{*}{ Demografik Özellikler } & \multicolumn{2}{|c|}{ Aktivite Skoru } & \multicolumn{2}{|c|}{ Duygusal Skor } & \multicolumn{2}{|c|}{ Semptom Skoru } & \multicolumn{2}{|c|}{ Toplam Skor } \\
\hline & $\mathbf{r}$ & $\mathbf{p}$ & $\mathbf{r}$ & $\mathbf{p}$ & $\mathbf{r}$ & $\mathbf{p}$ & $\mathbf{r}$ & $\mathbf{p}$ \\
\hline Yaş & 0,015 & 0,893 & 0,047 & 0,641 & 0,054 & 0,583 & 0,050 & 0,622 \\
\hline Cinsiyet & 0,150 & 0,136 & $-0,008$ & 0,934 & 0,137 & 0,175 & 0,118 & 0,242 \\
\hline Aylık gelir & 0,026 & 0,801 & 0,011 & 0,910 & 0,036 & 0,723 & 0,016 & 0,872 \\
\hline Pasif sigara maruziyeti & $-0,076$ & 0,453 & $-0,132$ & 0,189 & $-0,047$ & 0,640 & $-0,082$ & 0,415 \\
\hline Ailedeki birey sayısı & $-0,114$ & 0,259 & $-0,097$ & 0,338 & $-0,147$ & 0,145 & $-0,135$ & 0,180 \\
\hline
\end{tabular}

r korelasyon katsayısı olup 1 ile -1 arasında ilişkinin gücünü ve yönünü (-:negatif yönde ilişki) göstermektedir. p>0,05: \%95 güven aralığında istatistiksel anlamlılık olmadığını göstermektedir.

ÇAYKÖ: çocuklar için astım yaşam kalitesi ölçeği

\section{Tablo 4. Çalışmaya katılan hastaların klinik özellikleriyle ÇAYKÖ skorları arasındaki ilişki}

\begin{tabular}{|c|c|c|c|c|c|c|c|c|}
\hline \multirow[t]{2}{*}{ Klinik Özellikler } & \multicolumn{2}{|c|}{ Aktivite Skoru } & \multicolumn{2}{|c|}{ Duygusal Skor } & \multicolumn{2}{|c|}{ Semptom Skoru } & \multicolumn{2}{|c|}{ Toplam Skor } \\
\hline & $\mathbf{r}$ & $\mathbf{p}$ & $\mathbf{r}$ & $\mathbf{p}$ & $\mathbf{r}$ & $\mathbf{p}$ & $\mathbf{r}$ & $\mathbf{p}$ \\
\hline Astım yılı (3,77 yıl) & $-0,078$ & 0,440 & $-0,164$ & 0,103 & $-0,219 *$ & 0,028 & $-0,192$ & 0,056 \\
\hline Atak sıklığı (son 1 yıldaki) & $-0,199 *$ & 0,047 & $-0,266^{* *}$ & 0,007 & $-0,292$ ** & 0,003 & $-0,301 * *$ & 0,002 \\
\hline $\begin{array}{l}\text { Kısa etkili Beta-2 agonist } \\
\text { kullanma sıklığı (son } 3 \text { ayda) }\end{array}$ & $-0,330 * *$ & 0,001 & $-0,300 * *$ & 0,002 & $-0,478 * *$ & 0,000 & $-0,431 * *$ & 0,000 \\
\hline Okul devamsızlığı (gün) & $-0,306 * *$ & 0,002 & $-0,327$ ** & 0,001 & $-0,361 * *$ & 0,000 & $-0,378 * *$ & 0,000 \\
\hline Prick Testi pozitifliği & $-0,108$ & 0,285 & $-0,117$ & 0,245 & $-0,087$ & 0,392 & $-0,112$ & 0,265 \\
\hline
\end{tabular}

r korelasyon katsayısı olup 1 ile -1 arasında ilişkinin gücünü ve yönünü (-: negatif yönde ilişki) göstermektedir. *:p<0,05 istatistiksel anlamlılık olduğunu göstermektedir. **:p<0,01 daha güçlü istatistiksel anlamlılık olduğunu göstermektedir.

ÇAYKÖ: çocuklar için astım yaşam kalitesi ölçeği

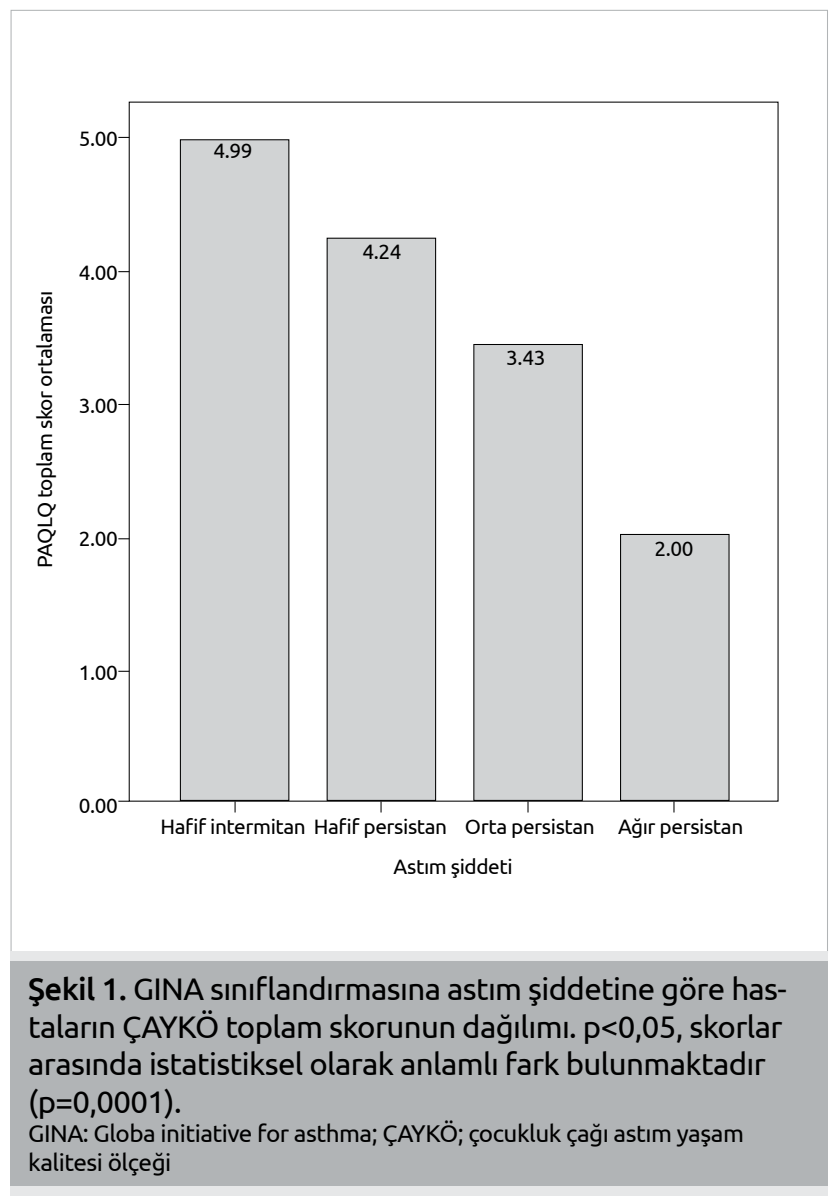

istatistiksel bir ilişki bulunmamıştır. Hastaların kullandıkları ilaç gruplarıyla ÇAYKÖ skorları arasındaki korelasyona bakıldığında inhale kortikosteroid kullanımıla ÇAYKÖ skorları arasında negatif yönde bir ilişki saptanmışırı $(r=-0,366$, $\mathrm{p}=0,002$ ). Lökotrien antagonisti kullanımıyla ÇAYKÖ skorları arasında anlamlı ilişki bulunamamıştır $(\mathrm{r}=-0,086$, $\mathrm{p}=0,884)$.

\section{Tartışma}

Çocukluk çă̆ı astımı hastaneye defalarca yatış, okul devamsızlı̆̆ı ve diğer günlük aktivitelerde azalma gibi sonuçlara neden olmaktadır. Astımı olan çocukların fiziksel, sosyal ve emosyonel durumları bozulmaktadır. Astım hastalığının kendisi, çocukların hatta ebeveynlerin bile yaşam kalitesini belirgin olarak etkileyebilmektedir (13). Çalışma sunuçlarımız, astımlı çocukların yaşam kalitesi skorlarının düşük olduğu göstermiştir. Ancak, çalışmamızın yapıldığı hastaneye başvuran hasta popülasyonunun sosyoekonomik koşullarının çok iyi olmamasının, demografik özelliklerin yaşam kalitesine istatistiksel olarak anlamlı bir etkisi olmadığını ve bu sonucun literatürle uyumlu olduğunu da göstermiştir. Çalışma grubumuzdaki hastaların, hastalık derecesi arttıkça, yaşam kalitesi göstergeleri de istatistiksel anlamlıkta düşmüştür. Hastalarımızın pasif sigara maruziyeti ve alerjik rinit öyküsü oranlarının yüksek olduğu ve bu faktörlerin yaşam kalitesini olumsuz etkilediği saptanmıştır. 
Nougeria ve ark.'nın (14), Brezilya'da yapmış oldukları çalışmada, bizim çalışmamızda olduğu gibi demografik özelliklerin çoğunun yaşam kalitesiyle ilişkili olmadığı, yaşam kalitesinin sadece eğitim düzeyi, pasif sigara maruziyeti, şiddetli astım ve 5 yıldan kısa tanı süresiyle istatistiksel olarak ilişkili olduğu görülmüştür. Bizim çalışmamızda ise astım tanı yılının artmasıyla yaşam kalitesi skorlarının azaldığı gözlenmiştir. Leynaert ve ark.'da (15), Fransa'da yapmış oldukları çalışmada, hastaların çoğunlukla orta derecede astımlı olması nedeniyle yaşam kalitesi ile demografik ve sosyoekonomik özellikler arasında bir ilişki olmadığını göstermişlerdir. Bu sonuçlar çalışmamızla paralellik göstermektedir.

Çalışmamızda, hastaların son 1 yılda yaşadıkları atak sayısı $1,74 \pm 2,02$, son 6 aydaki okul devamsızlığ $3,55 \pm 5,08$ gün ve son 3 aydaki kısa etkili beta-2 agonist kullanım sıklı̆̆ $1,39 \pm 1,29$ bulunmuştur. Çalışmaya katılan hastaların $\% 45^{\prime}$, GINA kılavuzuna göre hafif intermitan, \%29'u hafif persistan, $\% 25$ 'i orta persistan astım sinffinda iken, sadece 1 hastanın ağır persistan sınıfında olduğu saptanmıştır. Beklendiği gibi, hastaların astım şiddetinin artmasıyla yaşam kalitesi skorlarının azaldığı görülmüştür $(\mathrm{p}=0,0001)$. Çalışmamızda 7 puan üzerinden değerlendirilen ÇAYKÖ skorlarının genel olarak düşük olduğu saptanmıştır (aktivite skoru 3,94, duygusal skor 4,67, semptom skoru 4,31, toplam skor 4,35, Şekil 1). Boran ve ark.'ının (16) saptamış oldukları yaşam kalitesi skorlarının bizim çalışmamızdaki skorlardan daha yüksek olduğu görülmüştür. Bu farkın onların çalışmasındaki hasta popülasyonunun büyük bir kısmının (\%82) hafif intermitan astımlı olmasından kaynaklandığını düşünmekteyiz .

Çalışmamızda hastaların astım nedeniyle yapmakta zorlandığı üç faaliyetten en fazla seçtikleri faaliyetler koşma (\%66), futbol (\%36) ve merdiven çıkma (\%27) faaliyeti olmuştur. AlAkour ve ark.'nın (17), Ürdün'lü astımlı çocuklarda yapmış oldukları çalışmada hastaların yapmakta zorlandığı üç faaliyet koşma (\%52), arkadaşlarla oynama (\%43) ve futbol (\%38) olarak belirlenmiştir. Reichenberg ve ark.'nın çalışmasında $\mathrm{da}$ (18) İsveçli çocuklarda koşma (\%74), jimnastik (\%30) ve tepeye tırmanma (\%26) ilk üç sırada yer alan faaliyetler olmuştur. Bu çalışmalara dayanarak astımlı çocuklarda özellikle koşma ve futbol oynamanın hastaların yaşamlarını zorlaştıran sporlar olduğunu söyleyebiliriz.

Çalışmamızda pasif sigara maruziyeti ve evdeki birey sayısı ile yaşam kalite skorları arasında ters yönde ama zayıf bir korelasyon bulunmuştur. Türkiye'nin farklı bölgelerinde yapılmış olan çalışmalarda (19-21), genel olarak astımlı çocukların ailelerinde sigara kullanımının yaygın olduğunu görülmektedir. Çalışmamızda sigara içimi ile ÇAYKÖ skorları arasında istatistiki anlamlılık olmasa da evde sigara içimi olan hastalarda skorlar daha düşük bulunmuştur.

Çalışma grubumuzdaki astımlı hastalarda ilave alerjik rinit öyküsü \%64 oranındaydı. Alerjik rinit öyküsü bulunan hastaların ÇAYKÖ skorlarının, alerjik rinit öyküsü olmayan hastalara göre daha düşük olduğu gözlenmiştir; ancak bu fark, semptom skoru $(\mathrm{p}=0,043)$ dışındaki skorlar açısından istatistiksel olarak anlamlı bulunmamıştır. Pinto Pereira ve ark.'nın (22) Batı Hindistanlı astımlı çocuklar üzerinde yaptıkları çalışmada alerjik rinit oranı \%53,9 olarak bulunmuş ve bu çocukların diğerlerine göre daha fazla gündüz ve gece semptomu ve okul kaybı yaşadıkları saptanmıştır. Leynaert ve ark. (15), çalışmalarında astıma eşlik eden alerjik rinit oranını \%78 olarak saptamışlardır. Bizim çalışmamızdan daha yüksek bir oranda görülmesine karşın, alerjik rinitin eşlik ettiği astımlı çocukların tek başına alerjik riniti olanlara göre daha fazla fiziksel kısıtlama yaşadıklarını; ancak sosyal/mental sağlık açısından iki grup arasında anlamlı bir fark olmadığını görmüşlerdir. Boran ve ark. (16), alerjik rinitin eşlik ettiği astımlı çocuklarda emosyonel skor dışındaki semptom skoru ve aktivite skorunun alerjik rinitle güçlü negatif bir ilişkisi olduğunu saptamışlardır. Çalışmamızda ise sadece semptom skorunun istatistiksel olarak ilişkili olduğu bulunmuştur.

Çalışmamızda, korelasyon analizine göre hastaların astım tanısı konduktan sonra geçen süre arttıkça semptom skorlarının azaldığı görülmekteydi. Tanı yılıyla aktivite skoru, emosyonel skor ve toplam skor arasında negatif bir korelasyon olsa da bu ilişki istatistiksel açıdan anlamlı bulunmamıştır. Yüksel ve ark. (12), çalışmalarında astım tanı süresi 3 yıldan fazla olan çocuklarda toplam skorunun tanı yılı 3 ve 3 'ten az olanlara göre daha düşük olduğunu; ancak aktivite skoru ve semptom skorlarının daha yüksek olduğunu görmüşlerdir. Emosyonel skorla tanı yılı arasında ise, bizim çalışmamızda da olduğu gibi istatistiksel bir ilişki bulmamışlardır.

Çalışmamızda herhangi bir astım ilacı (bronkodilatör, inhale kortikosteroid, lökotrien antagonisti, spesifik immünoterapi) kullanan hastaların, astım ilacı kullanmayan hastalara göre ÇAYKÖ skorlarının beklendiği gibi daha düşük olduğu ve bu farkın her 4 skor türü için istatistiksel açıdan anlamlı olduğu görülmüştür $(\mathrm{p}<0,001)$. Nougeria ve ark.'nın (14) yapmış oldukları çalışmada da ilaç kullanan astımlı çocuklarda yaşam kalitesi skorlarının ilaç kullanmayanlara göre daha düşük olduğu görülmüştür. Araştırmacılar, astım ilacı kullanan hastaların genellikle daha şiddetli astım sınıfında olmalarından dolayı yaşam kalitelerinin olumsuz etkilendiğini ve bu sonucun beklendiği gibi çıktığını ifade etmişlerdir. Hastalarımızın inhale kortikosteroid kullanımıyla ÇAYKÖ skorları arasında negatif yönde bir ilişki saptanırken, lökotrien antagonisti kullanımıyla ÇAYKÖ skorları ilişkili bulunmamışır. Bunun da yukarıda belirtildiği gibi şiddetli astım olgularında inhale kortikosteroid kullanımın daha yaygın olmasından kaynaklandığını düşünmekteyiz. Boran ve ark.'nın da (16) inhale steroid kullanan astımlı çocuklarda toplam ve emosyonel yaşam kalitesi skorlarının inhale steroid kullanmayanlara göre daha düşük olduğunu bulmuşlardır.

\section{Sonuç}

Çalışmamızda, hastalık derecesinin artması, pasif sigara maruziyeti ve alerjik rinit öyküsünün, astımlı çocuk hastalarda yaşam kalitesini olumsuz etkilediği saptanmıştır. Çalışma 
popülasyonumuzun Türkiye'deki genel astımlı hasta profilini yansıttığını varsayarsak, bu hastalarda yaşam kalitesinin iyileştirilmesi için, öncelikle astım tedavisinin kontrol altında tutulması, evde sigara maruziyetinin azaltılması, beraberinde olan alerjik rinit bulgularının tedavi edilmesinin gerektiğini düşünüyoruz. Bulgularımızın ülkemizde, astımlı çocuklarla ilgili yapılacak diğer yaşam kalitesi çalışmalarına yol göstereceğine inanıoruz.

Ethics Committee Approval: Ethics committee approval was received for this study from the ethics committee of Bezmialem Vakif University.

Informed Consent: Written informed consent was obtained from parents of the patients who participated in this study.

Peer-review: Externally peer-reviewed.

Author Contributions: Concept - E.Ö.; Design - E.Ö.; Supervision - E.Ö.; Funding - E.Ö., Ö.S.; Materials - Ö.S., E.Ö.; Analysis and/or Interpretation - E.Ö.; Literature Review - Ö.S., M.R.D.; Writing - E.Ö.; Critical Review - M.R.D.

Conflict of Interest: No conflict of interest was declared by the authors.

Financial Disclosure: The authors declared that this study has received no financial support.

Etik Komite Onayı: Bu çalış̧ma için etik komite onayı Bezmialem Vakıf Üniversitesi klinik araştırmalar etik kurulu’ndan alınmıştır.

Hasta Onamı: Yazılı hasta onamı bu çalıșmaya katılan hastaların ebeveynlerinden alınmıştır.

Hakem değerlendirmesi: Dış bağımsız.

Yazar Katkıları: Yazar Katkıları: Fikir - E.Ö.; Tasarım - E.Ö.; Denetleme - E.Ö.; Kaynaklar - E.Ö., Ö.S.; Malzemeler - Ö.S., E.Ö.; Analiz ve/veya Yorum - E.Ö.; Literatür Taraması - Ö.S., M.R.D.; Yazıyı Yazan - E.Ö.; Eleştirel İnceleme - M.R.D.

Çıkar Çatışması: Yazarlar çıkar çatışması bildirmemişlerdir.

Finansal Destek: Yazarlar bu çalışma için finansal destek almadıklarını beyan etmişlerdir.

\section{Kaynaklar}

1. International Study of Asthma and Allergies in Childhood (ISAAC) Steering Committee. Worldwide variation in prevalence of symptoms of asthma, allergic rhinoconjuntivitis, and atopic eczema: ISAAC. Lancet 1998; 351: 1225-32. [CrossRef]

2. Saraçlar Y, Kuyucu S, Tuncer A, Şekerel B, Saçkesen C, Kocabaş C. Prevalence of asthmatic phenotypes and bronchial hyperresponsiveness in Turkish schoolchildren: an International Study of Asthma and Allergies in Childhood (ISAAC) phase 2 study. Ann Allergy Asthma Immunol 2003; 91: 477-84. [CrossRef]
3. Al-Akour N, Khader YS, Quality of life in Jordanian children with asthma. Int J Nurs Pract 2008; 14: 418-26. [CrossRef]

4. Zandieh F, Moin M, Movahedi M. Assessment of quality of life in Iranian asthmatic children, young adults and their caregivers. Iran J Allergy Asthma Immunol 2006; 5: 79-83.

5. Yorgancıoğlu A1, Özdemir C, Kalaycı Ö, Kalyoncu AF, Bachert C, Baena-Cagnani CE, et al. [ARIA (Allergic Rhinitis and its Impact on Asthma) achievements in 10 years and future needs]. Tuberk Toraks 2012; 60: 92-7. [CrossRef]

6. Başaran S, Güzel R, Sarpel T. Yaşam kalitesi ve sağlık sonuçlarını değerlendirme ölçütleri Romatizma 2005; 20: 55-63.

7. Ungar WJ, Boydell K, Dell S, Feldman BM, Marshall D, Willan A, et al. A parent-child dyad approach to the assessment of health status and health-related quality of life in children with asthma. Pharmacoeconomics 2012; 30: 697-12. [CrossRef]

8. Wilson SR, Rand CS, Cabana MD, Foggs MB, Halterman JS, Olson L, et al. Asthma outcomes: quality of life. J Allergy Clin Immunol 2012; 129: 88-123. [CrossRef]

9. Juniper EF. How Important Is Quality of Life in Pediatric Asthma? Pediatric Pulmonology (Suppl.) 1997; 15: 17-21. [CrossRef]

10. Nogueira KT, Silva JR, Lopes CS. Quality of life of asthmatic adolescents: assessment of asthma severity, comorbidity, and life style. J Pediatr (Rio J) 2009; 85: 523-30. [CrossRef]

11. Global Initiative for Asthma (GINA). Global strategy for asthma management and prevention. Updated 2008. Available on line at www.ginasthma.org/

12. Yüksel H, Yılmaz Ö, Kırmaz C, Eser E. Validity and reliability of the Turkish translation of Pediatric Asthma Quality of Life Questionnaire. Turk J Pediatr 2009; 51: 154-60.

13. Ozkaya E, Cetin M, Uğurad Z, Samanci N. Evaluation of family functioning and anxiety-depression parameters in mothers of children with asthma. Allergol Immunopathol (Madr) 2010; 38: 25-30. [CrossRef]

14. Nogueira KT, Silva JR, Lopes CS. Quality of life of asthmatic adolescents: assessment of asthma severity, comorbidity, and life style. J Pediatr (Rio J) 2009; 85: 523-30. [CrossRef]

15. Leynaert B, Neukirch C, Liard R, Bousquet J, Neukirch F. Quality of life in allergic rhinitis and asthma. A population-based study of young adults. Am J Respir Crit Care Med 2000; 162: 1391-6. [CrossRef]

16. Boran P, Tokuç G, Pişgin B, Oktem S. Assessment of quality of life in asthmatic Turkish children. Turk J Pediatr 2008; 50: 18-22.

17. Al-Akour N, Khader YS. Quality of life in Jordanian children with asthma. Int J Nurs Pract 2008; 14: 418-26. [CrossRef]

18. Reichenberg K, Broberg AG. Quality of life in childhood asthma: use of the Paediatric Asthma Quality of Life Questionnaire in a Swedish sample of children 7 to 9 years old. Acta Paediatr 2000; 89: 989-95. [CrossRef]

19. Kalyoncu AF, Selcuk ZT, Enunlu T, Demir AU, Coplu L, Sahin $\mathrm{AA}$, et al. Prevalence of asthma and allergic diseases in primary school children in Ankara, Turkey: two cross-sectional studies, five years apart. Pediatr Allergy Immunol 1999; 10: 261-5. [CrossRef]

20. Selcuk ZT, Caglar T, Enunlu T, Topal T. The prevalence of allergic diseases in primary school children in Edirne, Turkey. Clin Exp Allergy 1997; 27: 262-9. [CrossRef]

21. Cinar N, Dede C, Cevahir R, Sevimli D. Smoking status in parents of children hospitalized with a diagnosis of respiratory system disorders. Bosn J Basic Med Sci 2010; 10: 319-22.

22. Pinto Pereira LM, Jackman J, Figaro N, Babootee N, Cudjoe G, et al. Health burden of co-morbid asthma and allergic rhinitis in West Indian children. Allergol Immunopathol (Madr). 2010; 38: 129-34. [CrossRef] 